$\begin{array}{ll}\text { Received } & : 25 \text { March } 2019 \\ \text { Revised } & : 28 \text { March } 2019 \\ \text { Accepted } & : 11 \text { September } 2019 \\ \text { Published } & : \text { 27 Desember } 2019\end{array}$

\title{
Character Based Text for Development on V Grade Students of Elementary School
}

\author{
Burhanuddin Habibi Nasution $^{1, a)}$, Abdul Rahman ${ }^{1, b)}$, Syahnan Daulay ${ }^{2)}$ \\ ${ }^{1}$ Universitas Muslim Nusantara Al-Washliyah, Medan, Indonesia \\ ${ }^{2}$ Universitas Negeri Medan, Medan, Indonesia \\ E-mail: a)habibi_boy42@yahoo.co.id, b) dalimuntheabdulrahman@gmail.com
}

\begin{abstract}
Specifically, this study aims to (1) describe the design process for the development of character-based fairy tale text materials, (2) analyze the feasibility of character-based fairy tale text teaching materials, and (3) evaluate the effectiveness of character-based fairy tale text teaching materials in fifth grade students of SD Negeri 068084 Medan. The research method used is research and development with several research procedures. The procedure for $\mathrm{R} \& \mathrm{D}$ research is carried out through a cycle, which begins with a needs analysis. The results show that fairytale text based teaching materials that have been developed with a development pattern can be used as an alternative for character education delivery for V grade SD Negeri 068084 students. This character-based fairy tale is in very valid criteria, can be used without revision with a score of 82.35 for material experts and a score of 84.61 for design experts. As well as the effectiveness of character-based fairy tale text teaching materials in grade V SD Negeri 068084 Medan in the category of effective and feasible to use with an average score of 85.7 .
\end{abstract}

Keywords: teaching materials, fairytale, characters

\begin{abstract}
Abstrak
Secara spesifik, penelitian ini bertujuan untuk (1) mendeskripsikan proses rancangan pengembangan bahan ajar teks dongeng berbasis karakter, (2) menganalisis kelayakan bahan ajar teks dongeng berbasis karakter, dan (3) mengevaluasi keefektifan bahan ajar teks dongeng berbasis karakter pada siswa kelas V SD Negeri 068084 Medan. Metode penelitian yang digunakan adalah penelitian Research and Development dengan beberapa prosedur penelitian. Prosedur penelitian R \& D dilakukan melalui suatu siklus yang diawali dengan analisis kebutuhan. Hasil penelitian menunjukkan bahwa bahan ajar teks dongeng berbasis pendidikan karakter yang telah dikembangkan dengan pola pengembangan dapat dimanfaatkan sebagai alternatif penyampaian pendidikan karakter bagi siswa kelas V SDN 068084. Kelayakan bahan ajar teks dongeng berbasis karakter ini berada dalam kriteria sangat valid, dapat digunakan tanpa revisi dengan skor 82,35
\end{abstract}


AKSIS: Jurnal Pendidikan Bahasa dan Sastra Indonesia Volume 3 Nomor 2, Desember 2019
e-ISSN: 2580-9040

e-Jurnal: http://doi.org/10.21009/AKSIS

untuk ahli materi dan skor 84,61 untuk ahli desain. Keefektifan bahan ajar teks dongeng berbasis karakter pada siswa kelas V SDN 068084 Medan berada pada kategori efektif dan layak digunakan dengan skor rata-rata 85,7.

Kata kunci: bahan ajar, dongeng, karakter

\section{PENDAHULUAN}

Provinsi Sumatera Utara adalah wilayah yang pernah berkasus kebejatan moral seperti perlakuan begal dan pembunuhan berencana (Effendi, 2017). Hal tersebut sesuai dengan penelitian Sulistyawati (2015) yang pernah melihat kondisi dan kenyataan yang menyedihkan tersebut telah menimbulkan berbagai pertanyaan bagi berbagai pihak, baik di kalangan masyarakat umum maupun di kalangan para ahli pendidikan. Siapakah yang potensial mengatasi masalah kebejatan moral? Pertanyaan tersebut adalah pertanyaan retoris yang diatasi oleh kalangan pendidik juga.

Guru SD merupakan sumber daya manusia sinergik untuk mengatasi masalah kebejatan moral di Sumatera Utara. Guru SD yang berkualifikasi memiliki sikap religius dan bermoral Pancasilais akan dikuatkan lagi potensinya melalui pembekalan kemampuan menentukan sumber belajar dan media pembelajaran Bahasa Indonesia. Mereka perlunya mengawal siswanya supaya tidak terpengaruh terhadap sikap non-religius dan non-moralis walaupun mereka mengetahui peristiwa kebejatan dan tindak kriminal dalam tayangan telivisi atau komik maupun internet yang berlokasi di Sumatera Utara dan Indonesia. Selain itu, sebagai salah satu bagian dari insane pendidikan, guru memiliki tanggung jawab untuk memberikan pendidikan karakter. Pendidikan karakter merupakan pengajaran dan pembelajaran bagi perkembangan anak, khususnya pada aspek penalaran moral/pengembangan kognitif, pembelajaran sosial dan emosional, pendidikan moral, pendidikan keterampilan hidup, pendidikan kesehatan, pencegahan kekerasan, resolusi konflik, serta filsafat etik/moral (Amrullah dan Imayah, 2019).

Untungnya, keprihatinan tersebut sudah diakomodasi oleh Kurikulum 2013 sebagai landasan pendidikan di Indonesia. Pada Kurikulum 2013 untuk jenjang sekolah dasar, capaian pembelajaran didominasi oleh ranah sikap, ranah keterampilan, dan minimum dalam ranah kognitif. Dani (2013) mengklarifikasi bahwa pengantar pembelajaran dengan strategi pendongengan merupakan pemicu motorik berkapasitas afektif. Oleh karena itu, maka topik-topik pembelajarannya dalam pembelajaran Bahasa Indonesia dilangsungkan dalam koridor strategi dan model pendongengan terpenting untuk penguatan pendidikan sikap. Model pendongengan bagi siswa SD potensial untuk peciptaan kepekaan rasa karena bersentuhan dengan sifat geocultural-mythologisnya. Sosialisasi pembatinannya akan berdaya estetis yang sejajar dengan potensialisasi apresiasi dongeng yang diterima siswa melalui pembelajaran bahasa, khususnya bahasa Indonesia (Turan \& Ulutas 2016).

Dongeng-dongeng geo-cultural adalah wacana folklor geocultural-mythologies Sumatera Utara yang berpotensi menggagas, menstimuli, menggerakkan nilai-nilai keseimbangann hidup antara manusia dan alamnya (Danandjaja, 1999). Sukmawan (2016) menyatakan bahwa secara geoculutural-mythologies dongeng Sumatera Utara berkategorial dialek bahasa Melayu dan Batak. Sibarani (2012) dan Syaifuddin (2016) pun mengatakan bahwa dongeng atau tradisi masyarakat Melayu mempunyai 
kedudukan yang tinggi di dalam kehidupan masyarakat baik dalam masyarakat masa lalu maupun waktu kini. Di samping memancarkan nilai nilai kehidupan masyarakat Melayu, dongeng juga memancarkan segala pewarna jiwa, semangat, sikap kepercayaan dan sejarah ideologi dan cermin hidup dan hati nurani masyarakatnya (Lickona, 2012; Muslich, 2011). Syaifuddin (2016) menjelaskan bahwa potensi-potensi pedongengan Sumatera Utara berkaitan sama potensialnya dengan dongeng Nusantara untuk menjadikannya sebagai sumber belajar dan media pendidikan kontributif untuk penguatan mentalitas berlingkungan kenusantaraan, seperti legenda yang berglos pantai/laut, gunung/bukit, danau, rawa, benda, lokasi alam geocultural-mythologies Sumatera Utara.

Jika guru berperan sebagai pengubah dan pemberi pengaruh peserta didik dalam pembentukan karakter, perlu diperjelas pada posisi mana peran yang diharapkan atau bentuk peran seorang guru yang diharapkan bisa membentuk karakter peserta didik tersebut (Purwahida, 2017; Purwahida, 2018). Oleh karena itu, pengembangan bahan ajar teks dongeng berbasis karakter yang bisa dimanfaatkan dalam membentuk karakter peserta didik ke arah pencapaian yang lebih baik dalam menumbuhkan sifat-sifat karakter kebangsaan. Karakter sendiri dapat dimaknai sebagai kecenderungan individu untuk berpikir, merasakan, dan berperilaku sesuai etika yang relevan dengan moralitas (Cohen \& Morse, 2014).

Pengembangan bahan ajar teks dongeng berbasis karakter diharapkan mampu mendorong guru SD membuat dan juga melakukan pengajaran yang tepat, maka jalan yang paling sesuai yaitu mencoba menguraikan pengembangan bahan pembelajaran teks dongeng yang berbasis karakter sebagai alternatif dalam pembentukan karakter peserta didik dalam pengajaran bahasa Indonesia (Wardani \& Suhita, 2018). Diperlukan dukungan dari bahan belajar yang dapat digunakan untuk belajar secara mandiri. Apa lagi setiap siswa memiliki kecepatan belajarnya masing-masing. Selain itu, pengembangan bahan ajar teks dongeng berbasis setidaknya juga harus mengandung dan menyampaikan karakter-karakter dasar yang harus dimiliki anak di jenjang sekolah dasar antara lain kejujuran, disiplin, menghargai orang lain, teguh pada pendirian, dan bertanggung jawab (Klein-Ezell, Ezell, Stanley, \& Powell, 2014).

Akan tetapi, bahan belajar yang demikian serta dapat digunakan mandiri oleh siswa di rumah belum tersedia. Sebagian besar siswa belajar di rumah hanya menggunakan buku paket dan LKS. Guru belum mengembangkan bahan ajar yang dapat digunakan siswa belajar mandiri. Untuk mencapai hal tersebut akan lebih baik apabila memanfaatkan sarana dan prasarana di sekolah. Lebih dimungkinkan dikembangkan bahan belajar mandiri siswa yang berbentuk cetak. Modul merupakan salah satu bentuk dari bahan ajar cetak yang sering dijumpai.

Dengan demikian, masalah pada penelitian ini dirumuskan sebagai (1) bagaimana proses pengembangan bahan ajar teks dongeng berbasis karakter pada siswa kelas V SD Negeri 068084 Medan, (2) bagaimana kelayakan bahan ajar teks dongeng berbasis karakter pada siswa kelas V SD Negeri 068084 Medan, serta (3) bagaimana keefektifan bahan ajar teks dongeng berbasis karakter pada siswa kelas V SD Negeri 068084 Medan. Berdasarkan rumusan masalah tersebut, tujuan penelitian ini adalah mendeskripsikan proses, menganalisis kelayakan, serta mengevaluasi keefektifan pengembangan bahan ajar teks dongeng berbasis karakter pada siswa kelas V SD Negeri 068084 Medan. 


\section{METODE PENELITIAN}

Tulisan ini menggunakan jenis penelitian pengembangan (Research and Development). Metode penelitian dan pengembangan adalah metode penelitian yangdigunakan untuk menghasilkan produk tertentu dan menguji keefektifan produk tersebut. Di dalam Sugiyono (2014) menyatakan bahwa penelitian pengembangan adalah suatu proses yang digunakan untuk mengembangkan dan memvalidasi produkproduk yang digunakan dalam pendidikan danpembelajaran.

Prosedur pengembangan yang digunakan dalam mengadaptasi langkah kerja yang dikembangkan oleh Borg dan Gall. Prosedur tersebut dipilih karena memiliki langkah yang terperinci dan sederhana. Prosedur R \& D dari Borg dan Gall terdiri atas sepuluh langkah seperti yang diilustrasikan pada gambar berikut.

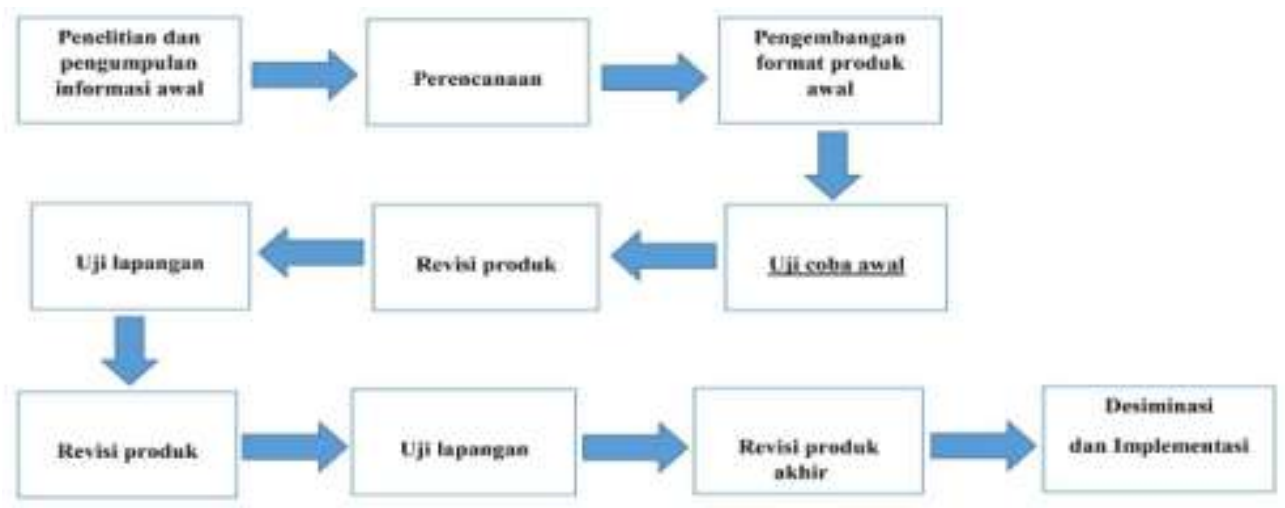

GAMBAR 1. Tahapan Penelitian Pengembangan

Pengumpulan data dilakukan di SD Negeri 068084 Medan, khususnya pada siswa kelas V. Teknik pengumpulan data yang digunakan ada empat macam, yakni teknik dokumentasi, teknik observasi, teknik wawancara, dan teknik angket/kuesioner. Selanjutnya, analisis data menggunakan analisis deskriptif berdasarkan hasil analisis data dari ahli/pakar dan uji coba produk. Kegiatan analisis data dilakukan dengan mencari rata-rata skor skala likert berdasarkan tiap-tiap aspek atau domain. Penilaian kuesioner dilakukan dengan kriteria $1=$ sangat kurang, 2=kurang, 3=cukup, 4=baik, dan $5=$ sangat baik. Setelah menghitung skor rata-rata seluruh kriteria penilaian, skor yang didapat diubah ke dalam hasil persentase/proporsi. Skor persentase diperoleh dengan cara menghitung rata-rata jawaban berdasarkan instrumen penilaian menurut para ahli, tiga guru Bahasa dan Sastra Indonesia, dan siswa SD kelas V.

\section{HASIL DAN PEMBAHASAN}

Hasil penelitian pengembangan bahan ajar teks dongeng berbasis karakter dijabarkan berdasarkan langkah-langkah pengembangan bahan ajar. Hasil penelitian pengembangan bahan ajar teks dongeng berbasis karakter dapat dilihat dari komponenkomponen, di antaranya (1) pengumpulan informasi (identifikasi kebutuhan bahan ajar terhadap guru), (2) desain produk, (3) validasi desain (menganalisis produk oleh pakar ahli), (4) perbaikan desain, (5) uji coba produk pertama, (6) revisi produk, (7) uji produk kedua, (8) penyempurnaan produk, (9) produksi massal, dan (10) uji massal. 


\section{Proses Pengembangan Bahan Ajar Teks Dongeng Berbasis Karakter}

Pada tahap proses pengembangan bahan ajar, aktivitas pertama yang dilakukan adalah pengumpulan data. Pengumpulan data dilakukan dengan mengidentifikasi kebutuhan bahan ajar teks dongeng berbasis karakter terhadap siswa dan guru. Hasil dari identifikasi dijabarkan dan disatukan dengan hal-hal yang perlu dibuat dalam pengembangan bahan ajar ini. Identifikasi kebutuhan bahan ajar teks dongeng berbasis karakter pada siswa dan guru adalah kegiatan penulis untuk memperoleh informasi kebutuhan bahan ajar pada siswa dan guru, dengan memberikan kuesioner kepada siswa dan gurudan melakukan wawancara terhadap guru. Informasi tersebut berasal dari siswa dan wali kelas V SD Negeri 068084 Medan.

Dari analisis kebutuhan bahan ajar untuk siswa dan guru, bisa disimpulkan beberapa hal sebagai berikut. Pertama, siswa sangat bersemangat dan tertarik belajar dongeng dan guru merasa senang mengajarkan materi dongeng, tetapi kurang terakomodasi oleh fasilitas yang disediakan. Kedua, kurang menariknya metode dan ketersediaannya buku pembelajaran serta alat ataupun bahan ajar yang berakibatkan sebagian siswa mempelajari dongeng diluar dari buku pelajaran. Ketiga, siswa kurang menyadari bahan ajar sebagai pembelajaran terpadu. Keempat, buku paket bahasa Indonesia yang digunakan kurang bisa dijadikan sebagai pembelajaran terpadu sesuai tuntunan kurikulum.

Setelah pengisian kuesioner, pengumpulan data dilanjutkan dengan metode wawancara. Wawancara dilakukan pada guru kelas V SD Negeri 068084 Medan melalui beberapa pertanyaan. Adapun hasil dari kegiatan wawancara tersebut dapat dijabarkan sebagai berikut.

Pertama, pemahaman guru terhadap fungsi bahan ajar cukup baik. Guru berpendapat bahwa fungsi bahan ajar bagi pendidik adalah sebagai alat bantu pendidik memahami materi pembelajaran. Hal itu juga diperkuat dengan hasil wawancara, guru menjelaskan jika fungsi membuat bahan ajar teks dongeng berbasis karakter adalah sebagai rambu-rambu guru mengajarkan sastra pada siswanya dan sebagai penumbuhan nilai karakter pada diri siswa. Dengan demikian, secara keseluruhan, guru mengetahui pentingnya bahan ajar, tetapi faktanya guru tidak memungkiri jika mereka tidak memahami apa bahan ajar teks dongeng. Hal tersebut dapat dilihat pada hasil wawancara berikutnya.

Kedua, pemahaman tentang bahan ajar teks dongeng berbasis karakter masih sangat dangkal. Di samping itu, guru juga mengharapkan bahan ajar teks dongeng berbasis karakter yang mudah dipahami guru dan siswa. Hal itu juga diperkuat dengan hasil wawancara, guru menyatakan jika bahan ajar teks dongeng berbasis karakter adalah cerita-cerita rakyat yang banyak berkembang di daerah masing-masing. Jadi, secara keseluruhan guru masih belum memahami apa yang dimaksud bahan ajar akan tetapi mereka memahami bentuk bahan ajar sastra yang disukai siswa yaitu bahan ajar teks dongeng berbasis karakter yang dekat dengan kehidupan dan kebudayaan siswa tersebut.

Ketiga, kendala yang dihadapi pendidik terhadap bahan ajar cukup kompleks, di antaranya sumber belajar tidak ada yang berorientasi pada teks dongeng berbasis karakter. Hal tersebut dipertegas dari hasil wawancara, guru menyatakan tidak tersedianya sumber belajar yang berorientasi pada dongeng berbasis karakter membuat guru sulit membuat bahan ajar yang berorientasi pada dongeng berbasis karakter khususnya dongeng daerah Sumatera Utara. 
Keempat, pemahaman pembuatan bahan ajar masih sangat kurang, karena guru tidak pernah membuat atau menyusun bahan ajar sastra. Hal tersebut juga dipertegas dalam wawancara, guru menyatakan belum pernah membuat bahan ajar sastra karena tidak adanya perhatian dari pemerintah daerah untuk mengadakan pelatihan pembuatan bahan ajar sastra dan penyediaan sumber untuk membuat bahan ajar sastra.

Kelima, karena guru tidak pernah membuat bahan ajar, guru tidak mengetahui struktur bahan ajar cetak yang baik. Akan tetapi, guru mengharapkan bahan ajar sastra yang dibuat mampu menarik minat belajar siswa. Hal itu dipertegas dalam wawancara, guru menyatakan bahan ajar yang menarik adalah Bahan ajar yang singkat jelas dan terperinci. Bahan ajar yang berbelit-belit akan menjemukan siswa. Berdasarkan pendapat tersebut, tampak bahwa pemahaman guru tentang bahan ajar cetak kurang. Namun, guru mengetahui bentuk bahan ajar yang disukai atau dapat meningkatkan minat belajar siswa.

Keenam, guru tidak pernah membuat modul dan modul yang digunakan sering tidak menarik minat belajar siswa. Akan tetapi, guru mengharapkan bahan ajar yang dihasilkan nantinya berbeda dan lebih baik dari yang sudah ada. Hal itu juga dipertegas dalam wawancara, guru menyatakan belum pernah membuat modul tetapi guru mengharapkan bahan ajar yang menarik, baik itu berupa alur cerita, gambar-gambar yang ada, maupun desain dari penerbit. Berdasarkan hal tersebut, guru juga mengharapkan udara segar dalam pembelajaran dongeng berbasis karakter di kelasnya dengan tujuan dapat meningkatkan minat belajar siswa dalam sastra dan menumbuhkan nilai karakter didalam diri siswa.

Setelah melakukan pengidentifikasian kebutuhan bahan ajar terhadap guru dan siswa, langkah selanjutnya adalah menganalisis kurikulum yang selama ini digunakan pada kegiatan belajar mengajar. Analisis kurikulum dilaksanakan untuk menentukan kompetensi-kompetensi yang akan dicapai dan mana yang membutuhkan bahan ajar. Hasil analisis kurikulum menunjukkan bahwa kompetensi inti dan kompetensi dasar sudah relevan, sehingga mempermudah menentukan indikator dan materi pembelajaran, dalam hal ini materi pembelajaran adalah cerita dongeng. Hasil analisis kurikulum juga menghasilkan data hubungan materi pembelajaran dengan bahan ajar sastra yang dikembangkan, jadi dapat disimpulkan jika bahan ajar sastra sesuai atau berhubungan dengan kurikulum.

Setelah melakukan pengindentifikasian kebutuhan teks dongeng berbasis karakter, langkah selanjutnya adalah mendesain produk bahan ajar teks dongeng berbasis karakter. Oleh karena banyaknya jumlah dongeng yang ada di Sumatera Utara, tidak semua dongeng diambil sebagai bahan penyusunan modul. Dengan demikian, dongeng perlu untuk dipilah sesuai dengan kebutuhan siswa. Adapun hasil dari indentifikasi kebutuhan teks dongeng yang dilakukan oleh penulis diuraikan dalam tabel berikut.

TABEL 1. Dongeng Sumatera Utara

\begin{tabular}{lll}
\hline No & \multicolumn{1}{c}{ Judul Dongeng } & \multicolumn{1}{c}{ Jenis } \\
\hline 1 & Asal Mula Kolam Sampuraga & Legenda \\
\hline 2 & Asal Mula Pulau Si Kantan & Legenda \\
\hline 3 & Danau Law Kawar & Mite \\
\hline 4 & Si Baroar & Sage \\
\hline 5 & Asal Mula Nama Simalungun & Legenda \\
\hline 6 & Asal Mula Danau Toba & Legenda \\
\hline 7 & Asal Mula Nama Tanjung Morawa & Legenda \\
\hline 8 & Kelana Sakti & Sage \\
\hline
\end{tabular}




\begin{tabular}{lll}
\hline 9 & Asal Mula Tuak Aren & Mite \\
\hline 10 & Danau Si Losung dan Danau Si Pinggan & Legenda \\
\hline 11 & Puteri Ular Dari Simalungun & Sage \\
\hline 12 & Lubuk Emas & Mite \\
\hline 13 & Puteri Hijau & Sage \\
\hline 14 & Si Tanduk Yang Panjang & Jenaka \\
\hline 15 & Ahmad Dan Ali & Jenaka
\end{tabular}

Berdasarkan identifikasi kebutuhan, dongeng-dongeng yang tertera dalam tabel tersebut masuk dalam kategori legenda, mite, sage, atau cerita jenaka. Untuk fabel, guru mengambil cerita Nusantara. Fabel yang dipilih sebagai bahan ajar sastra yaitu cerita Kancil dan Buaya yang disampaikan secara lisan.

\section{Kelayakan Bahan Ajar Teks Dongeng Berbasis Karakter}

Pada tahap uji kelayakan bahan ajar teks dongeng berbasis karakter, terdapat dosen sebagai ahli yang telah memvalidasi produk bahan ajar teks dongeng berbasis karakter sebelum diujicobakan. Hasil validasi tersebut mencakup beberapa aspek yang dijabarkan sebagai berikut.

Pertama, validator menyarankan untuk memperbaiki bahasa pada indikator pembelajaran sehingga mudah menentukan tujuan pembelajaran, misalnya, kata masingmasing diganti dengan kata tiap-tiap. Kedua, saran untuk menampilkan tema bahasan mulai dari awal halaman. Ketiga, gaya selingkung dalam penulisan isi halaman. Keempat, penulisan teks bacaan pada setiap halaman sebaiknya tidak terlalu padat. Kelima, validator menyarankan agar ukuran huruf sebaiknya agak besar atau Comic Sans MS 12 atau 14. Keenam, pada bagian teks penjelasan perhatikan tanda baca (,). Ketujuh, penggunaan bahasa serapan asing dituliskan dengan tulisan miring. Kedelapan, memperhatikan susunan kalimat harus sesuai dengan pola kalimat yang benar agar tidak menimbulkan banyak tafsir/ambiguitas. Kesembilan, perhatikan kalimat tanya pada evaluasi bahan ajar sehingga mudah dipahami oleh siswa. Kesepuluh, kontras warna kurang baik sehingga gambar terlihat kurang jelas. Berdasarkan hasil validasi, penulis menindaklanjuti dan memperbaikinya sesuai dengan petunjuk yang diberikan pakar ahli, mulai dari isi, kebahasan, sajian, dan kegrafikan. Setelah validasi materi langkah selanjutnya yaitu perbaikan desain.

Setelah bahan ajar teks dongeng berbasis karakter selesai diperbaiki, produk siap untuk dinilai oleh validator ahli materi dan ahli desain untuk uji kelayakannya seperti yang diuraikan pada tabel berikut. 
TABEL 2. Validasi Ahli Materi

\begin{tabular}{|c|c|c|c|c|c|c|}
\hline \multirow{2}{*}{ No. } & \multirow{2}{*}{ Aspek Penilaian } & \multirow{2}{*}{ Deskriptor } & \multicolumn{4}{|c|}{ Skala Nilai } \\
\hline & & & 1 & $\mathbf{2} 3$ & 4 & 5 \\
\hline \multirow[t]{6}{*}{1.} & Relevansi & $\begin{array}{l}\text { Materi relevan dengan kompetensi yang harus } \\
\text { dikuasai siswa }\end{array}$ & & & $\sqrt{ }$ & \\
\hline & & $\begin{array}{l}\text { Bahan ajar teks dongeng berbasis karakter } \\
\text { relevan dengan kompetensi yang harus } \\
\text { dikuasai }\end{array}$ & & & $\sqrt{ }$ & \\
\hline & & $\begin{array}{l}\text { Kelengkapan materi sesuai dengan tingkat } \\
\text { perkembangan siswa }\end{array}$ & & & $\sqrt{ }$ & \\
\hline & & Materi cukup memenuhi tuntutan kurikulum & & & $\sqrt{ }$ & \\
\hline & & $\begin{array}{l}\text { Ilustrasi bahan ajar sesuai dengan tingkat } \\
\text { perkembangan siswa }\end{array}$ & & & $\sqrt{ }$ & \\
\hline & & Ilustrasi media yang fungsional cukup & & & $\sqrt{ }$ & \\
\hline \multirow[t]{4}{*}{2.} & Keakuratan & $\begin{array}{l}\text { Materi yang disajikan sesuai dengan } \\
\text { kebenarankeilmuan }\end{array}$ & & & $\sqrt{ }$ & \\
\hline & & $\begin{array}{l}\text { Materi yang disajikan sesuai perkembangan } \\
\text { mutakhir }\end{array}$ & & & $\sqrt{ }$ & \\
\hline & & $\begin{array}{l}\text { Materi yang disajikan sesuai dengan kehidupan } \\
\text { sehari-hari }\end{array}$ & & & $\sqrt{ }$ & \\
\hline & & $\begin{array}{l}\text { Pengemasan materi dalam bahan ajar sesuai } \\
\text { dengan pendekatan keilmuan yang } \\
\text { bersangkutan (pendekatan saintifik) }\end{array}$ & & & $\sqrt{ }$ & \\
\hline \multirow[t]{3}{*}{3.} & Penyajian Materi & Menyajikan kompetensi yang harus dikuasai & & & & $\sqrt{ }$ \\
\hline & & Siswa dan memberikan amanat dan pemberian & & & & \\
\hline & & Penjelasan tentang nilai karakter di dalam teks & & & & \\
\hline \multirow[t]{2}{*}{4.} & Konsep Dasar Materi & Kesesuaian konsep Fungi & & & & $\sqrt{ }$ \\
\hline & & Kesesuaian konsep pelestarian lingkungan & & & $\sqrt{ }$ & \\
\hline \multirow[t]{4}{*}{5.} & Kesesuaian sajian & Mendorong rasa keingintahuan siswa & & & $\sqrt{ }$ & \\
\hline & dengan tuntutan & Mendorong terjadinya interaksi siswa & & & $\sqrt{ }$ & \\
\hline & $\begin{array}{l}\text { pembelajaranyang } \\
\text { terpusat pada siswa }\end{array}$ & $\begin{array}{l}\text { Mendorong siswa membangun } \\
\text { pengetahuannya sendiri }\end{array}$ & & & $\sqrt{ }$ & \\
\hline & & $\begin{array}{l}\text { Mendorong siswa untuk menumbuhkan nilai } \\
\text { karakter }\end{array}$ & & & $\sqrt{ }$ & \\
\hline
\end{tabular}

Saran perbaikan dan kesimpulan:

Nilai maksimal: $17 \times 5=85$

Nilai: $70 / 85 \times 100=82,35$

Dari tabel penilaian media dapat dijelaskan bahwa nilai yang dapat diberi oleh dosen ahli media sebanyak 82,35. Oleh karena itu, dapat dikatakan kelayakan materi bahan ajar teks dongeng sangat valid dan dapat digunakan tanpa revisi lagi sehingga dapat diujicobakan kepada siswa kelas V SDN 068084 Medan. 
TABEL 3. Validasi Ahli Desain

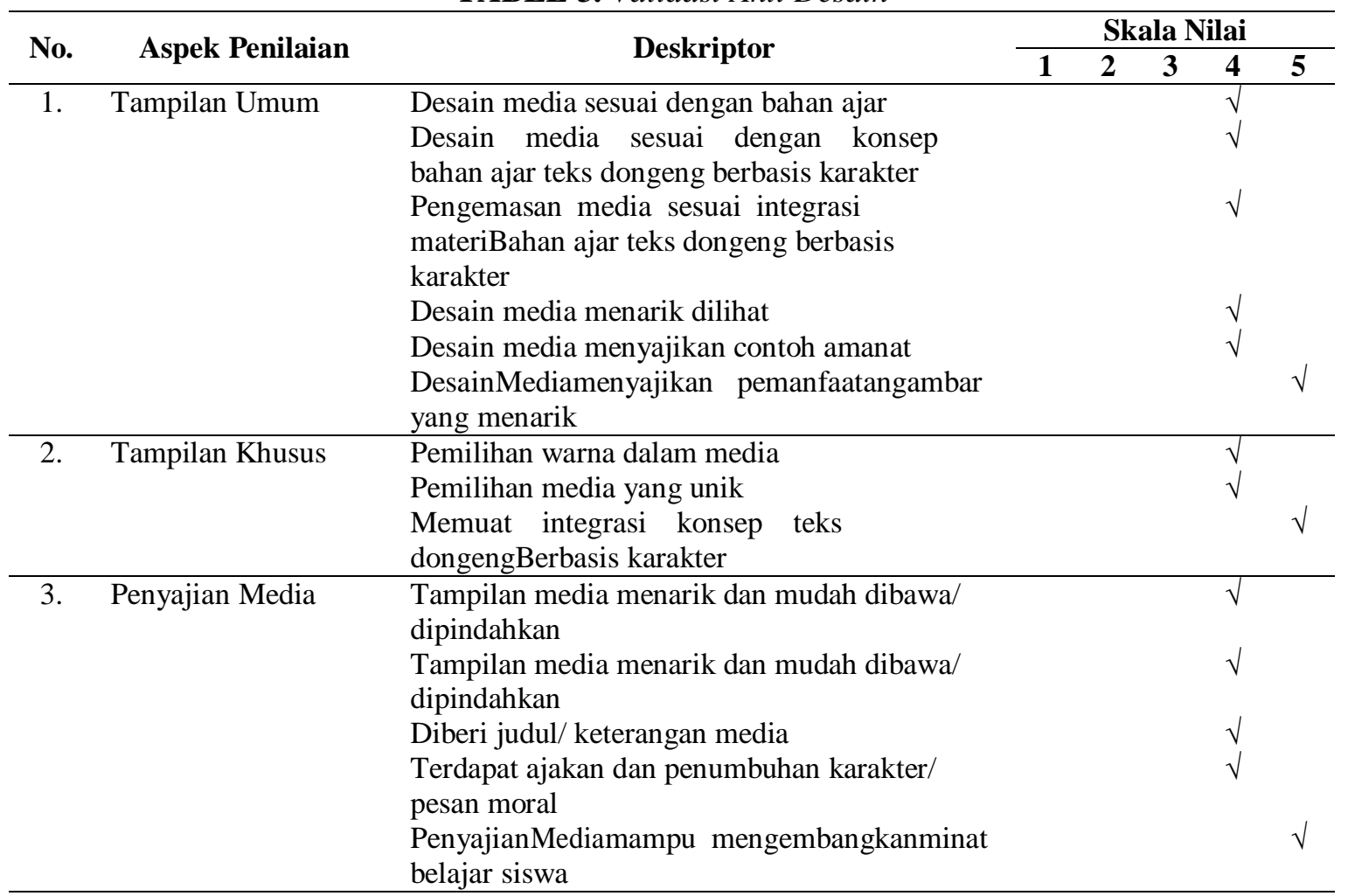

Saran perbaikan dan kesimpulan

Nilai Maksimal: $13 \times 5=65$

Nilai: $55 / 65 \times 100=84,61$

TABEL 4. Kriteria Kelayakan Secara Deskriptif

\begin{tabular}{cl}
\hline Kriteria Validitas & \multicolumn{1}{c}{ Tingkat Validitas } \\
\hline $81,0 \%-100,0 \%$ & Sangat valid, dapat digunakan tanpa revisi \\
$61,0 \%-80,9 \%$ & Cukup valid, dapat digunakan namun perlu revisi \\
$41,0 \%-60,9 \%$ & $\begin{array}{l}\text { Kurang valid, disarankan tidak digunakan karena perlu } \\
\text { revisi besar }\end{array}$ \\
$21,0 \%-40,9 \%$ & Tidak valid, tidak boleh dipergunakan \\
\hline
\end{tabular}

Dari tabel penilaian desain, nilai yang didapat sebesar 84,61 sehingga dikatakan kelayakan desain bahan ajar teks dongeng sangat valid dan dapat digunakan tanpa revisi lagi sehingga dapat di uji cobakan kepada siswa kelas V SDN 068084 Medan. Dengan demikian, bahan ajar teks dongeng berbasis karakter layak digunakan sebagai alternatif bahan ajar yang dapat mempermudah guru dan siswa dalam menyampaikan dan menanamkan pendidikan karakter kepada siswa dengan cara yang menyenangkan.

\section{Keefektifan Bahan Ajar Teks Dongeng Berbasis Karakter}

Kegiatan uji coba pertama dilakukan sebanyak dua kali pertemuan. Pertemuan pertama dilakukan pada hari Rabu, 3 April 2019, pukul 07.30 WIB sampai pukul 09.00 WIB. Pertemuan kedua dilakukan tepatnya pada hari Sabtu, 6 April 2019, pukul 09.30 WIB sampai 11.00 WIB. Kegiatan pembelajaran dilakukan oleh guru kelas V, sedangkan penulis mengobservasi kegiatan guru dan siswa terlebih dahulu. Penulis juga memberikan penilaian sikap siswa dalam kegiatan pembelajaran. Hasil perolehan nilai dan hasil penilaian sikap belajar siswa dapat dijelaskan berdasarkan uji coba produk 
pertama. Pada komponen kelayakan isi, beberapa indikator dinilai "cukup baik", di antaranya adalah indikator (1) kesesuaian antara KD dan indikator, (2) kesesuaian dengan kebutuhan siswa, (3) kesesuaian dengan kebutuhan bahan ajar, dan (4) kesesuaian dengan subtansi materi. Indikator manfaat wawasan pengetahun dan kesesuaian nilai sosial dan moral dinilai "baik". Selain itu, juga terdapat amanat dan imbauan pada setiap cerita mengenai nilai nilai karakter yang mengajak siswa untuk menumbuhkan nilai-nilai karakter kebangsaan tersebut.

Pada komponen kebahasaan, indikator kejelasan informasi dan efektifitas bahasa dinilai "cukup baik". Sedangkan indikator keterbacaan dan sesuai dengan KBI dinilai "baik". Pada komponen sajian, indikator kejelasan tujuan, sistematis, pemberian motivasi, dan kelengkapan informasi dinilai "baik". Stimulus dinilai "cukup baik". Pada komponen kegrafikan, jenis huruf, tata letak, desain, dan tampilan dinilai "baik". Secara keseluruhan nilai yang diperoleh oleh penulis masih kurang memuaskan. Oleh sebab itu, penulis berusaha memperbaiki bahan ajar teks dongeng berbasis karakter sehingga hasil evaluasi bahan ajar bisa lebih baik dengan nilai yangmemuaskan. Dengan demikian, penulis merasa perlu untuk merevisi bahan ajar berdasarkan masukan-masukan yang ada untuk mendapatkan nilai yang diharapkan. Setelah memperbaiki bahan ajar teks dongeng berbasis karakter, produk kembali diujikan ke uji coba produk yang kedua.

Kegiatan uji coba kedua dilakukan sebanyak dua kali pertemuan. Pertemuan pertama dilakukan pada hari Rabu, 24 April 2019, pukul 07.30 WIB sampai pukul 09.00 WIB. Pertemuan kedua dilakukan pada hari Sabtu, 27April 2019, pukul 07.30 WIB sampai 09.00 WIB. Kegiatan pembelajaran dilakukan oleh guru kelas V, sedangkan penulis mengobservasi kegiatan guru dan siswa terlebih dahulu. Penulis juga memberikan penilaian sikap siswa dalam kegiatan pembelajaran. Hasil perolehan nilai dan hasil penilaian sikap belajar siswa dapat kita lihat pada penjelasan berikut.

Berdasarkan data hasil latihan secara lisan pada uji coba kedua, dapat dijelaskan bahwa skor nilai seluruh subpokok materi mencapai rata-rata nilai 85,7, sedangkan jumlah siswa tuntas adalah 13 siswa atau 90\%. Dari data tersebut, diketahui juga kelas dinyatakan tuntas karena siswa yang memperolehnilai di atas 67 melampaui 85\% dari jumlah seluruh siswa di kelas.

Berdasarkan data uji coba produk kedua, hasil uji yang didapat dijelaskan sebagai berikut. Pada komponen kelayakan isi, beberapa indikator dinilai "sangat sesuai", di antaranya indikator (1) kesesuaian produk dengan KD dan SK, (2) kesesuaian kebutuhan bahan ajar, (3) kesesuaian dengan subtansi materi, dan (4) kesesuaian dengan nilai moral serta sosial. Selain itu, juga terdapat beberapa nilai karakter kebangsaan pada teks tersebut, sedangkan indikator manfaat wawasan pengetahun dan kesesuaian dengan kebutuhan siswa dinilai "baik".

Pada komponen kebahasaan semua indikator dinilai "sangat sesuai". Pada komponen sajian, indikator kejelasan tujuan, sistematis stimulus, dan kelengkapan informasi dinilai "sangat sesuai", sedangkan pemberian motivasi dinilai "baik". Pada komponen kegrafikaan, semua indikator dinilai "sangat sesuai". Secara keseluruhan, penilaian yang diperoleh oleh penulis sangat memuaskan. Oleh karena itu, penulis tidak perlu mengadakan uji produk yang ketiga. Akan tetapi, penulis tetap memperbaiki produk bahan ajar teks dongeng berbasis karakter berdasarkan masukan-masukan yang ada sebelum produk diproduksi massal untuk diujikan secara massal.

Berdasarkan hasil evaluasi bahan ajar teks dongeng berbasis karakter, penulis merasa puas dengan nilai yang diperoleh. Oleh karena itu, bahan ajar sastra sudah dapat dinyatakan layak guna dan efektif, tetapi perlu untuk diuji kembali 
keefektifannya, terutama aspek cakupan uji produk harus lebih luas, yaitu uji masal dengan mengujinya pada seluruh siswa kelas V SDN 068084 Medan.

Kegiatan uji produk secara massal dilakukan pada tanggal 27 April 2019 dengan jumlah subjek coba 29 siswa. Dari kegiatan uji produk bahan ajar teks dongeng berbasis karakter tersebut diperoleh hasil latihan secara lisan dan sikap siswa. Latihan secara lisan dilakukan per subbab materi pembelajaran, sehingga subbab pembelajaran dapat dimanfaatkan secara baik oleh siswa.

Berdasarkan data hasil latihan, hasil yang didapat adalah skor siswa untuk seluruh subpokok materi mencapai rata-rata nilai 78, sedangkan jumlah siswa tuntas sebayak 26 siswa atau 90\% dan tiga siswa belum tuntas karena hasil masih di bawah KKM sekolah yaitu 73. Dari data tersebut diketahui juga kelas dinyatakan tuntas karena siswa yang memperoleh nilai rata-rata 85,7 melampaui $85 \%$ dari jumlah seluruh siswa. Dengan demikian, penulis menyatakan bahan ajar teks dongeng berbasis karakter dapat diterima dengan baik.

Setelah itu, kegiatan dilanjutkan dengan penyebaran dan pengisian kuesioner pada wali kelas V SDN 068084 Medan di mana guru tersebut telah menggunakan bahan ajar teks dongeng berbasis karakter. Adapun hasil kuesioner yang diberikan pada guru tersebut diuraikan sebagai berikut.

Pertama, pada kriteria umum, responden menyatakan pembuatan bahan ajar teks dongeng berbasis karakter bisa dianggarkan dan disediakan oleh biaya sekolah. Kedua, pada kriteria khusus, responden menyatakan bahan ajar sastra mampu memotivasi dan mendukung pembelajaran sastra siswa di kelas. Ketiga, aspek kegunaan bahan ajar sudah memenuhi kriteria yang diharapkan di antaranya, mampu mengaktifkan belajar dan mudah dipahami. Keempat, tujuan bahan ajar, responden menyatakan siswa berinteraksi sangat baik dengan sastra dan membantu guru menyampikan materi. Kelima, bahan ajar bagi pembelajaran, banyak terdapat nilai-nilai karakter di dalam cerita sehingga mudah bagi guru menyampaikan pesan untuk menumbuhkan nilai karakter kebangsaan pada siswa. Selain itu, responden menyatakan modul mampu melibatkan siswa untuk aktif belajar. Keenam, responden menyatakan judul bahan ajar sudah sesuai dengan isi bahan ajar. Ketujuh, responden menyatakan petunjuk belajar pada bahan ajar mudah dipahami. Kedelapan, responden menyatakan materi sastra mudah diajarkan dan modul sudah berorientasi pada cerita rakyat Sumatera Utara.

Berdasarkan data respons guru terhadap bahan ajar teks dongeng berbasis karakter yang dilakukan dalam tahap uji coba massal, bahan ajar yang dikembangkan sudah dapat dikatakan layak guna walaupun masih harus direvisi lebih lanjut. Berdasarkan respons guru, penulis menindaklanjuti dengan merevisi kekurangan dari produk bahan ajar teks dongeng berbasis karakter agar lebih baik dari sebelumnya. Dengan demikian, bahan ajar yang dikembangkan akan dibukukan dan dicetak untuk dapat digunakan di SD Negeri 068084 Medan sebagai bahan ajar untuk penumbuhan karakter siswa.

\section{KESIMPULAN}

Berdasarkan hasil penelitian pengembangan modul teks dongeng berbasis karakter bagi siswa kelas V tingkat SD Negeri 068084 Medan dapat disimpulkan bahwa proses pengembangan bahan ajar teks dongeng berbasis karakter sangat dibutuhkan oleh guru dan siswa dalam melaksanakan kegiatan belajar mengajar yang lebih menarik dan dapat menumbuhkan nilai-nilai karakter kebangsaan di dalamnya. Oleh karena itu, produk yang dikembangkan efektif dan layak digunakan dengan kelayakan sangat valid. 
Bahan ajar tidak harus didapat dengan membeli tetapi dapat dibuat dan diciptakan sendiri. Oleh sebab itu, seorang guru harus terus menggali potensi diri dan potensi yang ada di lingkungan sekitar. Jadi, diharapkan dengan penulisan pengembangan bahan ajar teks dongeng berbasis karakter ini dapat membuka cakrawala pendidik untuk membuat bahan ajar untuk menumbuhkan nilai-nilai karakter kebangsaan serta meningkatkan minat belajar peserta didiknya. Akhirnya. siswa mampu mencapai indikator pembelajaran yang diharapkan oleh kurikulum.

\section{UCAPAN TERIMA KASIH}

Peneliti menyampaikan ucapan terima kasih kepada para seluruh dosen pengajar yang berada di Universitas Muslim Nusantara Al-Wasliyah sebagai lembaga legalisasi penelitian. Ucapan terima kasih juga disampaikan kepada Sekolah Dasar Negeri 068084 Medan atas pemberian izin untuk dapat melakukan penelitian disekolah tersebut dan tim redaksi Aksis atas saran dan masukan untuk perbaikan penulisan artikel ini.

\section{REFERENSI}

Amrullah, I., Imayah. (2019). Building students' characters through character education and religiousity values in Syair Kitab Ta'lim Muta'allim. Jurnal AKSIS: Jurnal Pendidikan Bahasa dan Sastra Indonesia, 3(1), 53-65. doi: https://doi.org/10.21009/AKSIS.030106

Cohen, T.R., \& Morse, L. (2014). Moral character: What it is and what it does. In A.P. Brief \& B.M. Staw (Eds.), Research in Organizational Behavior. Elsevier. Retrieved from https://www.researchgate.net/publication/264000952_Moral_character_What_it_i s_and_what_it_does

Danandjaja, J. (1999). Folklor Indonesia, Ilmu Gosip, Dongeng, dan Lain-Lain. Jakarta: Grafiti.

Dani, E.D. (2013). Pembentukan karakter anak melalui kegiatan mendongeng. .Jurnal Humanika, 17(1), 91-124. doi: 10.14710/humanika.17.1

Effendi, R. (2017, May 10). Hukum berat pembunuh keponakanku. Waspada, p. 5.

Klein-Ezell, C., Ezell, D., Stanley, S.P., \& Powell, S.E. (2014). Character education using children's literature, puppets, magic tricks and balloon art. International Journal of Humanities and Social Science, 4(14), 1-15.

Lickona, T. (2012). Character Matters. Jakarta: Bumi Aksara.

Muslich, M. (2011). Pendidikan Karakter Menjawab Tantangan Krisis Multidimensional. Jakarta: Bumi Aksara.

Purwahida, R. (2017). Interaksi sosial pada kumpulan cerpen Potongan Cerita di Kartu Pos karangan Agus Noor dan implikasinya terhadap pembelajaran sastra di SMA. Aksis: Jurnal Pendidikan Bahasa dan Sastra Indonesia 1(1). 118-134. doi: doi.org/10.21009/AKSIS.010107 
Purwahida, R. (2018). Problematika Pengembangan Modul Pembelajaran Baca Tulis Anak Usia Sekolah Dasar. Aksis: Jurnal Pendidikan Bahasa dan Sastra Indonesia 2(1). 118-134. doi: doi.org/10.21009/AKSIS.020108.

Sibarani, R. (2012). Local Wisdom: Hakikat, Peran, dan Metode Tradisi. Jakarta: ATL.

Sugiyono. (2014). Metode Penelitian dan Pengembangan (Research and Depelopment: R\&D). Bandung: Alfabeta.

Sukmawan, S. (2016). Ekokritik Sastra: Menanggap Sasmita Arcadia. Malang: Universitas Brawijaya Press.

Sulistyawati, Sri, Risnawaty, \& Purba, N. (2015). Model pembentukan karakter bangsa terhadap siswa SMA dalam mengantisipasi pencegahan tindak pidana korupsi di Sumatera Utara. Laporan Penelitian Tahap I: Unggulan Perguruan Tinggi. Medan: UMN Al Washliyah.

Syaifuddin, W. (2016). Pemikiran Kreatif \& Sastra Melayu Tradisi. Yogyakarta: Gading.

Turan, F., \& Ulutas, I. (2016). Using storybooks as character education tools. Journal of Education and Practice, 7(15), 169-176.

Wardani, Y. F. \& Suhita, S. (2018). Nilai Pendidikan Karakter dalam Novel Rindu Karangan Tere Liye: Tinjauan Psikologi Karakter. Aksis: Jurnal Pendidikan Bahasa dan Sastra Indonesia 2(2). 247-273. doi: doi.org/10.21009/AKSIS.020207 